\title{
A Review of Medicinal Uses, Phytochemistry and Biological Activities of Bolusanthus speciosus (Bolus) Harms (Fabaceae)
}

\author{
Alfred Maroyi
}

Department of Botany, University of Fort Hare, Private Bag X1314, Alice 5700, South Africa

\begin{abstract}
Bolusanthus speciosus (Bolus) Harms is a deciduous and ornamental tree with its different parts used traditionally to treat various diseases. The main aim of this review is to provide an overview and critical analysis of the medicinal uses, phytochemistry, and biological activities of $B$. speciosus. The information presented in this study was gathered using various databases such as PubMed, Taylor and Francis imprints, Springer, NCBI, Google scholar and Science direct, and review of books, journal articles and other scientific publications kept in the university library. The articles published between 1933 and 2020 were used in this study. The bark, leaf and stem infusion of B. speciosus are mainly used for cleansing blood and as an emetic, and a traditional medicine for abdominal pains, kidney problems, sexually transmitted infections and stomach problems. Phytochemical compounds identified from the leaves, root bark, root wood, seeds and stem bark of $B$. speciosus include alkaloids, essential oils, flavonoids, phenolics, saponins and tannins. The biological activities exhibited by $B$. speciosus and the phytochemical compounds isolated from the species include anti-arthritic, antibacterial, antigonococcal, antimycobacterial, antifungal, anti-HIV, anti-inflammatory and antioxidant activities. Future research should focus on toxicological screening, in vivo studies and clinical trials involving the crude extracts and phytochemical compounds isolated from the species.
\end{abstract}

Keywords: Bolusanthus speciosus, Fabaceae, indigenous knowledge, southern Africa, traditional medicine.

\section{INTRODUCTION}

Bolusanthus speciosus (Bolus) Harms is a deciduous tree indigenous to Botswana, Eswatini, South Africa, Malawi, Botswana, Zimbabwe, Mozambique and Zambia [1-7]. The species has also been introduced in Uganda, Australia, India, Kenya and several other countries throughout the world as an ornamental plant [8]. The genus Bolusanthus Harms comprises of a single species and the genus name is in the honour of Dr Harry Bolus (1834-1911), a South African businessman, botanist, botanical artist and founder of the Bolus Herbarium in Cape Town, South Africa [9]. The specific name "speciosus" is the Latin word for "beautiful" or "splendid" as the species is horticulturally attractive and showy [10]. The synonym of $B$. speciosus is Lonchocarpus speciosus Bolus while the English common names of the species include "elephant wood", "Rhodesian wistaria", "South African wistaria", "tree wistaria" and "wild wistaria". Bolusanthus speciosus is a small deciduous tree, usually multi-stemmed with narrow crown and drooping foliage. The bark of $B$. speciosus on young branches is smooth and grey, but dark grey to black, rough and deeply fissured longitudinally on older branches and stems. The leaves are spirally arranged and imparipinnate with lanceolate leaflets, which are greyish green in colour with minute silvery hairs above

*Address correspondence to this author at the Department of Botany, University of Fort Hare, Private Bag X1314, Alice 5700, South Africa; Tel/Fax: +27406022322; E-mail: amaroyi@ufh.ac.za

ISSN: 2223-3806 / E-ISSN: 1927-5951/20 and dull green below. The flowers of $B$. speciosus occur in loose, hanging racemes and are pale blue to deep mauve in colour. The fruit is a narrow, thin and flat non-splitting pod, which is straw-coloured to greybrown when ripe. Bolusanthus speciosus has been recorded in granite basaltic, heavy alkaline clay, limestone and calcareous soils in bushveld, thicket and open woodland and wooded grassland at an altitude ranging from $15 \mathrm{~m}$ to $1400 \mathrm{~m}$ above sea level [11-15]. Apart from being used as medicinal plant, $B$. speciosus is also an important forage plant throughout its distributional range in southern Africa [16]. Moreover, there is a patent registered in 1996 highlighting the potential clinical applications of a dihydro-isoflavonone compound isolated from the leaves, roots and stem bark of $B$. speciosus, which exhibited anti-HIV and anticancer activities [17]. It is this background that formed the basis of this study aimed at providing an overview of the medicinal uses, phytochemistry and biological activities of $B$. speciosus.

\section{Medicinal Uses}

The bark, leaf and stem infusion of $B$. speciosus are mainly used for cleansing blood and as an emetic, and a traditional medicine for abdominal pains, kidney problems, sexually transmitted infections (including venereal diseases) and stomach problems (Table 1; Figure 1). Other minor medicinal uses of $B$. speciosus supported by at least one literature report include the use of the bark, leaf and stem infusion to induce sleeping [18] and vomiting [8], an ethnoveterinary

(c) 2020 SET Publisher 
Table 1: Medicinal Uses of Bolusanthus speciosus

\begin{tabular}{|c|c|c|c|}
\hline Medicinal use & Part used & Country & Reference \\
\hline Abdominal pains & Bark and root decoction taken orally & Eswatini, Malawi and South Africa & {$[8,10,21-27]$} \\
\hline Ascites & Root infusion taken orally & Eswatini & [20] \\
\hline Bile emesis (vomiting bile) & Leaf decoction taken orally & Zimbabwe & [21] \\
\hline Cleansing blood & $\begin{array}{l}\text { Bark, leaf and stem infusion applied as } \\
\text { an enema }\end{array}$ & South Africa & [28-30] \\
\hline Emetic & Root decoction taken orally & South Africa and Zimbabwe & {$[21,26]$} \\
\hline Induce sleeping & Root infusion taken orally & South Africa & [18] \\
\hline Kidney problems & $\begin{array}{l}\text { Bark, leaf and stem infusion applied as } \\
\text { an enema }\end{array}$ & South Africa & [28-30] \\
\hline $\begin{array}{l}\text { Sexually transmitted infections } \\
\text { (including venereal diseases) }\end{array}$ & $\begin{array}{l}\text { Bark, leaf and stem infusion applied as } \\
\text { an enema }\end{array}$ & South Africa & [28-30] \\
\hline Sterility & $\begin{array}{l}\text { Roots mixed with the latex of } \\
\text { Tabernaemontana elegans Stapf }\end{array}$ & Zimbabwe & [21] \\
\hline Stomach problems & Bark and root decoction taken orally & Eswatini and South Africa & {$[8,23,24,26,31]$} \\
\hline Vomiting & Leaf infusion taken orally & Zimbabwe & [8] \\
\hline $\begin{array}{l}\text { Ethnoveterinary medicine (retained } \\
\text { placenta) }\end{array}$ & Roots & South Africa & [19] \\
\hline
\end{tabular}

medicine to expel retained placenta [19], and as a traditional medicine against ascites [20] and bile emesis [21]. In Zimbabwe, the roots of $B$. speciosus are mixed with the latex of Tabernaemontana elegans Stapf as a traditional medicine for sterility [21].

\section{Nutritional and Phytochemical Composition}

Researchers such as Aganga et al. [15], Mulaudzi et al. [29] and Vambe et al. [30] investigated the nutritional properties of $B$. speciosus bark, leaves and stems (Table 2). This wide variety of nutrients such as calcium, copper, crude fibre, fat, iron, magnesium, manganese, phosphorus, proteins and zinc imply that the species could be a source of health promoting nutrients to animals that consume the species as fodder. Phytochemical compounds identified from the leaves, root bark, root wood, seeds and stem bark of $B$. speciosus include alkaloids, essential oils, flavonoids, phenolics, saponins and tannins [29,30,32-38].

\section{Pharmacological Properties}

The following pharmacological activities have been documented from bark, leaves and stems, and phytochemical compounds isolated from B. speciosus: anti-arthritic, antibacterial, antigonococcal, antimycobacterial, antifungal, anti-HIV, antiinflammatory and antioxidant activities.

\section{Anti-Arthritic Activities}

Elisha et al. [39] evaluated the anti-arthritic activities of acetone extract of $B$. speciosus leaves using an

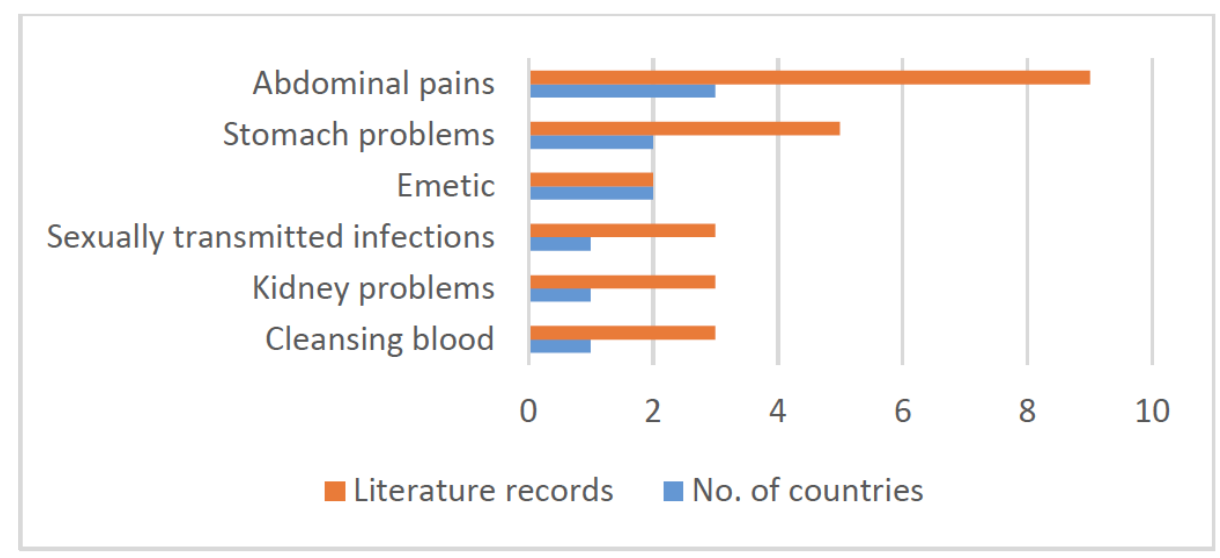

Figure 1: Major medicinal uses of Bolusanthus speciosus in southern Africa. 
Table 2: Nutritional and Phytochemical Composition of Bolusanthus speciosus

\begin{tabular}{|c|c|c|c|}
\hline Nutritional and phytochemical composition & Value & Plant part & Reference \\
\hline Acid detergent fibre (\%) & 19.3 & Leaves & [15] \\
\hline Ash (g/kg dry matter) & 2.1 & Leaves & {$[15]$} \\
\hline Calcium (\%) & 0.1 & Leaves & [15] \\
\hline Crude fat (g/kg dry matter) & 10.2 & Leaves & [15] \\
\hline Crude protein (g/kg dry matter) & 13.6 & Leaves & [15] \\
\hline Dry matter (\%) & 98.3 & Leaves & {$[15]$} \\
\hline Flavonoids ( $\mu \mathrm{g} \mathrm{CAE} / \mathrm{g}$ ) & $0.04-0.3$ & Bark, leaves and stems & [29] \\
\hline Iron (ppm) & 29.0 & Leaves & {$[15]$} \\
\hline Magnesium (\%) & 0.09 & Leaves & [15] \\
\hline Manganese (ppm) & 27.0 & Leaves & [15] \\
\hline Neutral detergent fibre (\%) & 6.7 & Leaves & [15] \\
\hline Phosphorus (\%) & 0.3 & Leaves & {$[15]$} \\
\hline Tannins (\%) & 1.4 & Leaves & {$[15]$} \\
\hline Total flavonoids (mg CE/g) & 5.0 & Bark & {$[30]$} \\
\hline Zinc (ppm) & 0.3 & Leaves & {$[15]$} \\
\hline $\begin{array}{l}\text { 2-Naphthalenemethanol, decahydro- } \alpha, \alpha, 4 a-t r i m e t h y l-8-m e t h y l e n e-, \\
\qquad(2 \alpha, 4 \alpha, 8 \beta](\%)\end{array}$ & 1.0 & Stem bark & [38] \\
\hline 3'-O-methylorobol & - & Seeds & [32] \\
\hline 3'-O-methylpratensein & - & Seeds & [32] \\
\hline 3-hydroxyisoflavanone bolusanthin & - & Seeds & [32] \\
\hline 5,6-dehydrolupanine & - & Leaves, seeds and stem bark & [33] \\
\hline $3,5,7,3^{\prime}, 4^{\prime}$-pentahydroxy-6- $y, \gamma$-dimethylallylflavone & - & Stem bark & [34] \\
\hline $4,2^{\prime}, 3^{\prime}, 4^{\prime}$-tetrahydroxy-6,7-methylenedioxyisoflavonol & - & Root bark & [36] \\
\hline $4,7,2$ '-trihydroxy-4'-methoxyisoflavanol & - & Root bark and stem bark & {$[35,36]$} \\
\hline 5,7,2'-trihydroxy-4'-methoxy-6,5'-diprenylisoflavanone & - & Root bark & [36] \\
\hline 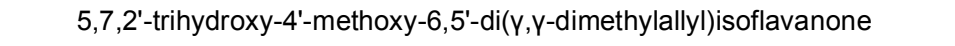 & - & Root bark and stem bark & [34-36] \\
\hline 5,7,2',4'-tetrahydroxy-8,3'-diprenylisoflavanone & - & Root bark & [36] \\
\hline 5,7,2',4'-tetrahydroxy-8,3'-di(y,y-dimethylallyl)isoflavanone & - & Root bark and stem bark & [34-36] \\
\hline 5,7,2',4'-tetrahydroxy-8,5'-di( $(\gamma, \gamma$-dimethylallyl)flavavone & - & Stem bark & [35] \\
\hline 5,7,3'-trihydroxy-4'-methoxy-5'-,$- \gamma$-dimethylallylisoflavanone & - & Root bark and stem bark & [34-36] \\
\hline 5,7,3'-trihydroxy-4'-methoxy-5'-prenylisoflavanone & - & Root bark & [36] \\
\hline
\end{tabular}


(Table 2). Continued.

\begin{tabular}{|c|c|c|c|}
\hline Nutritional and phytochemical composition & Value & Plant part & Reference \\
\hline 5,7,3',4'-tetrahydroxy-5'-(2-epoxy-3-methylbutyl)isoflavanone & - & Stem bark & [35] \\
\hline 5,7,3',4'-tetrahydroxy-5'-(2,3-epoxy-3-methylbutyl)isoflavanone & - & Root bark & [36] \\
\hline $5,7,3^{\prime}, 4^{\prime}$-tetrahydroxy-5'-,,$\gamma$-dimethylallyl-isoflavanone & - & Root bark & {$[36]$} \\
\hline 5,7,4'-trihydroxy-6,3'-di( $(\gamma, \gamma$-dimethylallyl)isoflavanone & - & Root bark & [36] \\
\hline $6 \beta$-hydroxylupanine & - & Leaves & [33] \\
\hline 7-hydroxy-4'-methoxyisoflavone & - & Root wood & [37] \\
\hline 7,3'-dihydroxy-4'-methoxyisoflavone & - & Root wood & [37] \\
\hline $11 \alpha$-allylcytisine & - & Leaves, seeds and stem bark & [33] \\
\hline 13-hydroxyanagyrine & - & Leaves, seeds and stem bark & [33] \\
\hline Acetic acid, butyl ester (\%) & 5.7 & Stem bark & [38] \\
\hline Anagyrine & - & Leaves, seeds and stem bark & {$[33]$} \\
\hline Azulene (\%) & 0.1 & Stem bark & [38] \\
\hline Biochanin A & - & Seeds & {$[32]$} \\
\hline Bolucarpan A - D & - & Root bark & [36] \\
\hline Bolusanthin II - IV & - & Root bark & {$[36,37]$} \\
\hline Bolusanthols A - C & - & Stem bark & [34] \\
\hline Caryophyllene (\%) & 16.3 & Stem bark & [38] \\
\hline a-caryophylene (\%) & 1.0 & Stem bark & [38] \\
\hline a-cubebene (\%) & 0.1 & Stem bark & [38] \\
\hline Cytisine & - & Leaves, seeds and stem bark & [33] \\
\hline Derrone & - & $\begin{array}{c}\text { Root bark, root wood and stem } \\
\text { bark }\end{array}$ & {$[35-37]$} \\
\hline Ethylbenzene (\%) & 8.3 & Stem bark & [38] \\
\hline Gancaonin C & - & Root wood & [37] \\
\hline Genistein & - & Root wood and seeds & {$[32,37]$} \\
\hline$\beta$-isosparteine & - & Leaves and seeds & [33] \\
\hline Isogancaonin C & - & Root wood & [37] \\
\hline Lupanine & - & Leaves and seeds & [33] \\
\hline Lupiwighteone & - & Root wood & [37] \\
\hline Medicarpan & - & Root wood & [37] \\
\hline N-methylcytisine & - & Leaves, seeds and stem bark & [33] \\
\hline Orobol & - & Seeds & [32] \\
\hline Pratensein & - & Seeds & [32] \\
\hline p-Xylene (\%) & 9.1 & Stem bark & [38] \\
\hline Sparteine & - & Leaves, seeds and stem bark & [33] \\
\hline Total phenolics (mg GAE/g) & $8.7-15.0$ & Bark, leaves and stems & {$[29,30]$} \\
\hline Wighteone & - & Root wood & [37] \\
\hline
\end{tabular}

anti-protein denaturation assay with diclofenac sodium as a positive control. The extract exhibited dose dependent activities and exhibited the half maximal inhibitory concentration $\left(\mathrm{IC}_{50}\right)$ value of $110.0 \mu \mathrm{g} / \mathrm{ml}$, which was higher than the $\mathrm{IC}_{50}$ value of $32.4 \mu \mathrm{g} / \mathrm{ml}$ exhibited by the positive control [39].

\section{Antibacterial Activities}

Bojase et al. [35] evaluated the antibacterial activities of the isoflavanoid compounds, 4,7,2' trihydroxy-4'-methoxyisoflavanol and $5,7,3^{\prime}, 4^{\prime}$ 'tetrahydroxy-5'-(2-epoxy-3-methylbutyl)isoflavanone 
isolated from the stem bark of $B$. speciosus against Escherichia coli, Bacillus subtilis and Staphylococcus aureus using the TLC bioautography technique with chloramphenicol as a positive control. The compound 5,7,3',4'-tetrahydroxy-5'-(2-epoxy-3-methylbutyl)isoflavanone exhibited the best activities against the tested pathogens with minimum inhibitory concentration (MIC) values ranging from $1.0 \mu \mathrm{g}$ to $10.0 \mu \mathrm{g}$ [35]. Bojase et al. [36] evaluated the antibacterial activities of the compounds bolusanthin II, bolucarpan A, bolucarpan B, bolucarpan C, bolucarpan D, 5,7,3'-trihydroxy-4'methoxy-5'-prenylisoflavanone, $\quad 5,7,2^{\prime}$-trihydroxy-4'methoxy-6,5'-diprenylisoflavanone, $\quad 5,7,2^{\prime}, 4^{\prime}$ tetrahydroxy-8,3'-diprenylisoflavanone, $\quad 4,2^{\prime}, 3^{\prime}, 4^{\prime}$ tetrahydroxy-6,7-methylenedioxyisoflavonol, $\quad 4,7,2^{\prime}-$ trihydroxy-4'-methoxyisoflavanol, 5,7,3',4'-tetrahydroxy5'-y,y-dimethylallyl-isoflavanone, 5,7,4'-trihydroxy-6,3'$\operatorname{di}\left(Y, Y\right.$-dimethylallyl)isoflavanone and $5,7,3^{\prime}, 4^{\prime}-$ tetrahydroxy-5'-(2,3-epoxy-3-methylbutyl)isoflavanone isolated from the root bark of $B$. speciosus against Escherichia coli, Bacillus subtilis and Staphylococcus aureus using the TLC bioautography technique with chloramphenicol as a positive control. All compounds with the exception of bolucarpan $C$ exhibited activities against the tested pathogens with MIC values ranging from $0.01 \mu \mathrm{g}$ to $100.0 \mu \mathrm{g}$ [36]. Erasto et al. [37] evaluated the antibacterial activities of the flavonoids, 7-hydroxy-4'-methoxyisoflavone, 7,3'-dihydroxy-4'methoxyisoflavone, bolusanthin III, bolusanthin IV, derrone, gancaonin C, genistein, isogancaonin C, lupiwighteone, medicarpan and wighteone isolated from the root wood of $B$. speciosus against Escherichia coli, Bacillus subtilis and Staphylococcus aureus using the TLC bioautography technique with chloramphenicol as a positive control. The compounds exhibited activities against the tested pathogens with the MIC values ranging from $0.1 \mu \mathrm{g}$ to $100.0 \mu \mathrm{g}$ [37]. Mulaudzi et al. [29] investigated the antibacterial activities of acetone, aqueous, petroleum ether and dichloromethane extracts of $B$. speciosus bark, leaves and stems against Staphylococcus aureus, Bacillus subtilis, Klebsiella pneumoniae and Escherichia coli using the microdilution method with neomycin as a positive control. The extracts exhibited activities against the tested pathogens with the MIC values ranging from $0.01 \mathrm{mg} / \mathrm{ml}$ to $>12.0 \mathrm{mg} / \mathrm{ml}$ [29]. Elisha et al. [40] evaluated the antibacterial activities of acetone extract of $B$. speciosus leaves against Bacillus anthracis using the microplate serial dilution method with gentamicin as a positive control. The extract exhibited activities with the MIC value of $0.04 \mathrm{mg} / \mathrm{ml}$ and total antibacterial activity of $576.0 \mathrm{ml} / \mathrm{g}$ [40]. Elisha et al. [41] evaluated the antibacterial activities of acetone extract of $B$. speciosus leaves against Proteus mirabilis, Stenotrophomonas maltophilia, Escherichia coli, Klebsiella pneumoniae, Enterobacter cloacae and Salmonella typhimurium using microdilution method with gentamicin as a positive control. The extract exhibited activities with MIC values ranging from 0.08 $\mathrm{mg} / \mathrm{ml}$ to $0.6 \mathrm{mg} / \mathrm{ml}$ and total antibacterial activity values ranging from $36.6 \mathrm{ml} / \mathrm{g}$ to $287.9 \mathrm{ml} / \mathrm{g}$ [41]. Elisha et al. [42] evaluated the antibacterial activities of acetone extract of $B$. speciosus leaves against Pseudomonas aeruginosa, Escherichia coli, Enterococcus faecalis, Staphylococcus aureus, Salmonella typhimurium and Bacillus cereus using the microplate serial dilution method with gentamicin as a positive control. The extract exhibited activities with MIC values ranging from $0.08 \mathrm{mg} / \mathrm{ml}$ to $0.5 \mathrm{mg} / \mathrm{ml}$ and total antibacterial activity ranging from $51.2 \mathrm{ml} / \mathrm{g}$ to $287.9 \mathrm{ml} / \mathrm{g}$ [42]. Vambe et al. [30] evaluated the antibacterial activities of methanol extract of $B$. speciosus bark against multidrug-resistant Escherichia coli and Klebsiella pneumoniae using microdilution assay. The authors also evaluated the antibacterial synergistic interactions of the extracts combined with antibiotics, ampicillin, cefotaxime, chloramphenicol and penicillin against Escherichia coli and Klebsiella pneumoniae using the checkerboard titration method and the time-kill assay. The extract exhibited activities against Escherichia coli and Klebsiella pneumoniae with MIC values of $0.6 \mathrm{mg} / \mathrm{ml}$ and $1.3 \mathrm{mg} / \mathrm{ml}$, respectively. The checkerboard assay detected antibacterial synergistic interactions in combinations with chloramphenicol against Escherichia coli [30].

\section{Antigonococcal Activities}

Mulaudzi et al. [29] evaluated the antigonococcal activities of acetone, petroleum ether and dichloromethane extracts of $B$. speciosus bark, leaves and stems against Neisseria gonorrhoeae through determination of clear zones of inhibition with ciprofloxacin as a positive controls. The extracts exhibited moderate to high activities with percentage inhibition ranging from $44.0 \%$ to $75.0 \%$ [29]. Vambe et al. [30] evaluated the antigonococcal activities of water, dichloromethane, methanol and petroleum ether extracts of $B$. speciosus bark against Neisseria gonorrhoeae using microdilution and agar disk diffusion techniques. The extracts exhibited activities against the tested pathogen with MIC values ranging from 0.6 $\mathrm{mg} / \mathrm{ml}$ to $>2.5 \mathrm{mg} / \mathrm{ml}[30]$.

\section{Antimycobacterial Activities}

Elisha et al. [43] evaluated the antimycobacterial activities of acetone extract of $B$. speciosus leaves 
against Mycobacterium smegmatis, Mycobacterium aurum and Mycobacterium fortuitum using the microdilution method with rifampicin and streptomycin as positive controls. The extracts exhibited activities against the tested pathogens with MIC values ranging from $1.3 \mathrm{mg} / \mathrm{ml}$ to $2.5 \mathrm{mg} / \mathrm{ml}$ and the total antimycobacterial activity values ranging from $9.2 \mathrm{ml} / \mathrm{g}$ to $18.4 \mathrm{ml} / \mathrm{g}$. The positive controls exhibited the MIC values ranging from $0.01 \mathrm{mg} / \mathrm{ml}$ to $0.06 \mathrm{mg} / \mathrm{ml}$ [43].

\section{Antifungal Activities}

Bojase et al. [36] evaluated the antifungal activities of the compounds bolusanthin II, bolucarpan A, bolucarpan B, bolucarpan C, bolucarpan D, 5,7,3'trihydroxy-4'-methoxy-5'-prenylisoflavanone, 5,7,2'-trihydroxy-4'-methoxy-6,5'-diprenylisoflavanone, 5,7,2',4'tetrahydroxy-8,3'-diprenylisoflavanone, $\quad 4,2^{\prime}, 3^{\prime}, 4^{\prime}$ tetrahydroxy-6,7-methylenedioxyisoflavonol, 4,7,2'trihydroxy-4'-methoxyisoflavanol, 5,7,3',4'-tetrahydroxy5'- $y, \gamma$-dimethylallyl-isoflavanone, 5,7,4'-trihydroxy-6,3'di $\left(Y, Y^{-d i m e t h y l a l l y l) i s o f l a v a n o n e ~ a n d ~} 5,7,3^{\prime}, 4^{\prime}-\right.$ tetrahydroxy-5'-(2,3-epoxy-3-methylbutyl)isoflavanone isolated from the root bark of $B$. speciosus against Candida cerevisiae and Candida mycoderma using the TLC bioautography technique with miconazole as a positive control. All the compounds exhibited activities against the tested pathogens with MIC values ranging from $0.01 \mu \mathrm{g}$ to $10.0 \mu \mathrm{g}$ [36]. Erasto et al. [37] evaluated the antifungal activities of the flavonoids, 7hydroxy-4'-methoxyisoflavone, 7,3'-dihydroxy-4'methoxyisoflavone, bolusanthin III, bolusanthin IV, derrone, gancaonin C, genistein, isogancaonin C, lupiwighteone, medicarpan and wighteone isolated from the root wood of $B$. speciosus against Candida mycoderma using the TLC bioautography technique with miconazole as a positive control. The compounds exhibited activities against tested pathogen with the MIC values ranging from $0.05 \mu \mathrm{g}$ to $10.0 \mu \mathrm{g}$ [37]. Mulaudzi et al. [29] investigated the antifungal activities of acetone, aqueous, petroleum ether and dichloromethane extracts of $B$. speciosus bark, leaves and stems against Candida albicans using the microdilution method with amphotericin $B$ as a positive control. The extracts exhibited activities against the tested pathogen with MIC and minimum fungicidal concentration (MFC) values ranging from $0.01 \mathrm{mg} / \mathrm{ml}$ to $6.3 \mathrm{mg} / \mathrm{ml}$ and $0.01 \mathrm{mg} / \mathrm{ml}$ to $12.5 \mathrm{mg} / \mathrm{ml}$, respectively [29].

\section{Anti-HIV Activities}

Mulaudzi et al. [29] evaluated the anti-HIV activities of aqueous and methanol extracts of $B$. speciosus bark, leaves and stems against a non-radioactive HIV-1 reverse transcriptase colorimetric ELISA kit with combivir and kaletra as positive controls. The extracts exhibited activities with inhibition percentage of $70.0 \%$ at $1.0 \mathrm{mg} / \mathrm{ml}$ and $\mathrm{IC}_{50}$ values ranging from $0.03 \mathrm{mg} / \mathrm{ml}$ to $0.4 \mathrm{mg} / \mathrm{ml}$, which were comparable to $\mathrm{IC}_{50}$ values of $0.06 \mathrm{mg} / \mathrm{ml}$ to $0.3 \mathrm{mg} / \mathrm{ml}$ exhibited by the positive control [29].

\section{Anti-Inflammatory Activities}

Mulaudzi et al. [44] evaluated the anti-inflammatory activities of $80 \%$ ethanol, water, dichloromethane and petroleum ether extracts of $B$. speciosus bark, leaves and stems against the cyclooxygenase (COX-1 and COX-2) enzymes. The $80 \%$ ethanol, dichloromethane and petroleum ether extracts exhibited activities towards both COX-1 and COX-2 with percentage inhibition of at least $50.0 \%$ [44]. Elisha et al. [39] evaluated the anti-inflammatory activities of acetone extract of $B$. speciosus leaves by determining the inhibition of nitric oxide production in lipopolysaccharide activated RAW 264.7 macrophages as well as 15-lipoxygenase enzyme inhibition. The extract exhibited activities by inhibiting nitric oxide production in a dose-dependent manner in the LPSstimulated RAW 264.7 macrophages with NO production of $61.4 \%$ at a concentration of $30.0 \mu \mathrm{g} / \mathrm{ml}$. The extract exhibited activities against 15-lipoxygenase enzyme with an $\mathrm{IC}_{50}$ value of $40.0 \mu \mathrm{g} / \mathrm{ml}$, which was lower than an $\mathrm{IC}_{50}$ value of $53.7 \mu \mathrm{g} / \mathrm{ml}$ exhibited by the positive control quercetin [39].

\section{Antioxidant Activities}

Erasto et al. [37] evaluated the antioxidant activities of the flavonoids, 7-hydroxy-4'-methoxyisoflavone, 7,3'dihydroxy-4'-methoxyisoflavone, bolusanthin III, bolusanthin IV, derrone, gancaonin $\mathrm{C}$, genistein, isogancaonin $\mathrm{C}$, lupiwighteone, medicarpan and wighteone isolated from the root wood of $B$. speciosus using the 2,2-diphenyl-1-picrylhydrazyl or 2,2-diphenyl1-(2,4,6-trinitrophenyl)-hydrazyl (DPPH) free radical scavenging and TLC autographic assays with quercetin, gallic acid and ascorbic acid as positive controls. The compounds 7,3'-dihydroxy-4'methoxyisoflavone, blusanthin III and bolusanthin IV exhibited the best activities with an $\mathrm{IC}_{50}$ values in DPPH ranging from $11.0 \mu \mathrm{g} / \mathrm{ml}$ to $150.0 \mu \mathrm{g} / \mathrm{ml}$ and TLC values ranging from $0.1 \mu \mathrm{g}$ to $0.5 \mu \mathrm{g}$ [37]. Elisha et al. [39] evaluated the antioxidant activities of acetone extract of $B$. speciosus leaves using the 2,2'-azinobis3-ethylbenzothiazoline-6-sulphonate (ABTS), DPPH free radical scavenging, ferric reducing power (FRAP) 
and the trolox equivalent antioxidant capacity (TEAC) assays with ascorbic acid and trolox as positive controls. The extract exhibited activities with an $\mathrm{IC}_{50}$ values of $60.0 \mu \mathrm{g} / \mathrm{mL}$ and $115.1 \mu \mathrm{g} / \mathrm{mL}$ in ABTS and $\mathrm{DPPH}$, respectively, which were higher than an $\mathrm{IC}_{50}$ values ranging from $2.9 \mu \mathrm{g} / \mathrm{mL}$ to $5.6 \mu \mathrm{g} / \mathrm{mL}$ exhibited by the two positive controls. The FRAP and TEAC values were 0.07 and 0.1 , respectively, while the positive controls showed values ranging from 1.0 to 3.7 [39].

\section{CONCLUSION}

While several ethnopharmacological studies aimed at evaluating the phytochemical composition and pharmacological properties of crude extracts and compounds isolated from $B$. speciosus have been conducted, few studies focused on toxicological properties of the species. Toxicological screening, in vivo studies and clinical trials should ideally be performed in parallel with therapeutic screening studies to allow the safety index to also be reported. In addition to this, it is important to conduct toxicological studies involving more than one toxicity model.

\section{AUTHOR'S CONTRIBUTIONS}

The author declares that this work was done by the author named in this article.

\section{CONFLICT OF INTEREST}

The author declares that there is no conflict of interest regarding the publication of this paper.

\section{REFERENCES}

[1] Drummond RB. A list of Rhodesian legumes. Kirkia 1972; 8(2): 209-29.

[2] Drummond RB. A list of trees, shrubs and woody climbers indigenous or naturalised in Rhodesia. Kirkia 1975; 10: 22985.

[3] Mapaura A, Timberlake J. A checklist of Zimbabwean vascular plants. Pretoria: Southern African Botanical Diversity Network Report No. 33; 2004.

[4] Setshogo MP. Preliminary checklist of the plants of Botswana. Pretoria: Southern African Botanical Diversity Network Report No. 37; 2005.

[5] Grant R. Sappi tree spotting: Lowveld including Kruger National Park. Johannesburg: Jacana Media (Pty) Ltd; 2007.

[6] Da Silva MC, Izidine S, Amude AB. A preliminary checklist of the vascular plants of Mozambique. Pretoria: Southern African Botanical Diversity Network Report No. 30; 2004.

[7] Burrows JE, Burrows SM, Lötter MC, Schmidt E. Trees and shrubs of Mozambique. Cape Town: Publishing Print Matters (Pty); 2018.

[8] Lemmens RHMJ. Bolusanthus speciosus (Bolus) Harms. In Louppe $D$, Oteng-Amoako AA, Brink $M$ (Editors), Plant resources of tropical Africa 7: timbers 1. Leiden: Backhuys Publishers, 2008, pp. 115-6.
[9] Palmer E, Pitman N. Trees of southern Africa, covering all known indigenous species in the Republic of South Africa, South-West Africa, Botswana, Lesotho and Swaziland. Cape Town: AA Balkema; 1972

[10] Palgrave MC. Keith Coates Palgrave trees of southern Africa. Cape Town: Struik Publishers; 2002.

[11] Steedman EC. Some trees, shrubs and lianes of southern Rhodesia. Salisbury: Rhodesian Printing and Publishing Co.; 1933.

[12] Germishuizen G, Meyer NL. Plants of southern Africa: An annotated checklist. Pretoria: Strelitzia 14, National Botanical Institute; 2003.

[13] Brummitt RK, et al. Leguminosae Subfamily Papilionoideae. In Timberlake JR, et al. (Eds.), Flora Zambesiaca volume 3, part 3. Richmond: Royal Botanic Gardens, Kew; 2007, pp. 1406.

[14] Van Wyk B, Van Wyk P. How to identify trees in southern Africa. Cape Town: Struik Nature; 2007.

[15] Van Wyk B, Van Wyk P. Field guide to trees of southern Africa. Cape Town: Struik Nature; 2013.

[16] Aganga AA, et al. Significance of browses in the nutrition of Tswana goats. Arch Zootec 2000; 49: 469-80.

[17] Chavunduka GL, Mashava PN. Isolation of naturally occurring isoflavanone and some clinical uses thereof. PCT/AP96/00002, issued April, 1996.

[18] Liengme CA. Plants used by the Tsonga people of Gazankulu. Bothalia 1981; 13: 501-18 https://doi.org/10.4102/abc.v13i3/4.1357

[19] Luseba D, Tshisikhawe MP. Medicinal plants used in the treatment of livestock diseases in Vhembe region, Limpopo province, South Africa. J Med Plants Res 2013; 7(10): 593601.

[20] Amusan OOG. Ethical and environmental issues in bioprospecting for drugs through traditional medicine: The case of Swaziland. Afr J Plant Sci Biotechnol 2008; 2(1): 1-9.

[21] Gelfand $M$, et al. The traditional medical practitioner in Zimbabwe: His principles of practice and pharmacopoeia. Gweru: Mambo Press; 1985.

[22] Amusan OOG, et al. Some herbal remedies from Manzini region of Swaziland. J Ethnopharmacol 2002; 79: 109-12. https://doi.org/10.1016/S0378-8741(01)00381-6

[23] Klapwijk N. Bolusanthus speciosus. National Botanical Garden, Pretoria; 2003. Available from: http://pza.sanbi.org/bolusanthus-speciosus, accessed on 21 May 2020

[24] Long C. Swaziland's flora: siSwati names and uses. Mbambane, Swaziland: Swaziland National Trust Commission; 2005. Available at: http://www.sntc.org.sz/ index.asp, accessed on 14 February 2020.

[25] Amusan OOG. Herbal medicine in Swaziland: An overview. In Juliani HR, Simon JE, Ho C-T (Eds.), African natural plant products: New discoveries and challenges in chemistry and quality. Washington DC: American Chemical Society; 2010, pp. 31-49. https://doi.org/10.1021/bk-2009-1021.ch003

[26] Venter F, Venter J-A. Making the most of indigenous trees. Pretoria: Briza Publications; 2015.

[27] Schmidt E, Lotter M, McCleland W. Trees and shrubs of Mpumalanga and Kruger National Park. Johannesburg: Jacana Media; 2017.

[28] Mabogo NED. The ethnobotany of the Vhavenda. MSc Dissertation. Pretoria: University of Pretoria; 1990.

[29] Mulaudzi RB, et al. Antimicrobial properties and phenolic contents of medicinal plants used by the Venda people for conditions related to venereal diseases. J Ethnopharmacol 2011; 135: 330-7.

https://doi.org/10.1016/j.jep.2011.03.022 
[30] Vambe M, et al. Antibacterial screening, synergy studies and phenolic content of seven South African medicinal plants against drug-sensitive and -resistant microbial strains. S Afr J Bot 2018: 114: 250-9.

https://doi.org/10.1016/j.sajb.2017.11.011

[31] Loffler L, Loffler P. Swaziland tree atlas: Including selected shrubs and climbers. Pretoria: Southern African Botanical Diversity Network Report No. 38; 2005.

[32] Asres $\mathrm{K}$, et al. Isoflavanoids from Bolusanthus speciosus (Bolus) Harms Leguminosae. Z Naturforsch 1985; 40C: 61720.

https://doi.org/10.1515/znc-1985-9-1005

[33] Asres K, Phillipson JD, Mascagani P. Alkaloids of Bolusanthus speciosus. Phytochem 1986; 25: 1449-52. https://doi.org/10.1016/S0031-9422(00)81307-2

[34] Bojase G, Wanjala CCW, Majinda RRT. Flavonoids from the stem bark of Bolusanthus speciosus. Phytochem 2001; 56: 837-41. https://doi.org/10.1016/S0031-9422(01)00009-7

[35] Bojase G, Wanjala CCW, Majinda RRT. Two new isoflavonoids from Bolusanthus speciosus. Bull Chem Soc Ethiop 2001; 15: 131-6.

[36] Bojase G, et al. Antimicrobial flavonoids from Bolusanthus speciosus. Planta Med 2002; 68(7): 615-20. https://doi.org/10.1055/s-2002-32910

[37] Erasto P, Bojase-Moleta G, Majinda RRT. Antimicrobial and antioxidant flavonoids from the root wood of Bolusanthus speciosus. Phytochem 2004; 65: 875-80. https://doi.org/10.1016/j.phytochem.2004.02.011

[38] Mtunzi F, et al. GC-MS analysis of hexane extract of Bolusanthus speciosus stem bark. Asian J Plant Sci Res 2013; 3(2): 27-30.
[39] Elisha IL, et al. The anti-arthritic, anti-inflammatory, antioxidant activity and relationships with total phenolics and total flavonoids of nine South African plants used traditionally to treat arthritis. BMC Compl Alt Med 2016; 16: 307. https://doi.org/10.1186/s12906-016-1301-z

[40] Elisha IL, et al. The efficacy and safety of nine South African medicinal plants in controlling Bacillus anthracis Sterne vaccine strain. BMC Compl Alt Med 2016; 16: 5. https://doi.org/10.1186/s12906-015-0980-1

[41] Elisha IL, et al. Potency and selectivity indices of acetone leaf extracts of nine selected South African trees against six opportunistic Enterobacteriaceae isolates from commercial chicken eggs. BMC Compl Alt Med 2017; 17: 90. https://doi.org/10.1186/s12906-017-1597-3

[42] Elisha IL, et al. The antibacterial activity of extracts of nine plant species with good activity against Escherichia coli against five other bacteria and cytotoxicity of extracts. BMC Compl Alt Med 2017; 17: 133

https://doi.org/10.1186/s12906-017-1645-z

[43] Elisha IL, et al. Acetone leaf extracts of some South African trees with high activity against Escherichia coli also have good antimycobacterial activity and selectivity index. BMC Compl Alt Med 2017; 17: 327. https://doi.org/10.1186/s12906-017-1831-z

[44] Mulaudzi RB, et al. Anti-inflammatory and mutagenic evaluation of medicinal plants used by Venda people against venereal and related diseases. J Ethnopharmacol 2013; 146: 173-9. https://doi.org/10.1016/j.jep.2012.12.026

DOI: https://doi.org/10.29169/1927-5951.2020.10.05.9

(C) 2020 Alfred Maroyi; Licensee SET Publisher.

This is an open access article licensed under the terms of the Creative Commons Attribution Non-Commercial License (http://creativecommons.org/licenses/by-nc/3.0/) which permits unrestricted, non-commercial use, distribution and reproduction in any medium, provided the work is properly cited. 